\title{
|Identidades e direitos da pessoa com transtorno mental
}

\author{
Identities and rights of people with mental disorder
}

Erotilde Honório Silva

Médica (UFC), Historiadora (UECE) e Comunicadora Social (UFC). Mestre e Doutora em Sociologia pela Universidade Federal do Ceará (UFC). Pesquisadora, Professora e Diretora de Comunicação e Marketing da Universidade de Fortaleza (UNIFOR).

\begin{abstract}
A presente resenha é fruto da apresentação que ocorreu no lançamento do livro Identidades e Direitos da Pessoa com Transtorno Mental, de autoria de Manoel Valente Figueiredo Neto, no auditório central da Universidade de Fortaleza, Ceará, em 19 de novembro de 2013.

Registro a minha satisfação e a honra de conhecer essa obra e poder emitir a minha modesta opinião. Identidade, uma das categorias estudadas no trabalho de Manoel Valente, faz parte da minha busca acadêmica e tive oportunidade de aplicá-la em algumas pesquisas, como em minha tese de doutorado e no grupo de pesquisa "Sofrimento psíquico: sujeito, sociedade e cultura" que ora desenvolvo na Universidade de Fortaleza. Daí o gosto, a curiosidade e o trato com o tema. O autor utiliza o recurso da História de Vida, que também compõe o corpo metodológico dos meus estudos nas mesmas oportunidades e no livro "O Despertar da Memória".

Ao ler a obra fui tomada por ímpar admiração pelo modo como Manoel Valente a desenvolveu. A sequência dos capítulos se encaixam de uma forma natural, complementar e absolutamente pertinentes. Não quero expor-me em elogios que beire ao sensacional, mas não me excuso de afirmar que é o trabalho mais completo que encontro dentro da Academia nos últimos anos, em várias participações em bancas de mestrado e doutorado e apresentações de livros. Como trabalho acadêmico, ele é tecnicamente perfeito.

Manoel Valente Figueiredo Neto nos brinda no início do livro com o resumo da sua fundamentação teórica, na qual cada teórico apresentado complementa o pensamento do outro de forma a tornar cada vez mais claro os caminhos pelos quais o autor vai conduzindo o leitor para o pleno entendimento de sua análise. Chama a atenção o cuidado do autor em citar os trabalhos já realizados com temas assemelhados e paralelos, já desenvolvidos no cenário de sua atuação, não tão conhecidos nacionalmente, mas de igual importância, o que revela o olhar valorativo do autor. O fato de não se fixar exclusivamente nos teóricos consagrados e por todos conhecidos e apresentar seus parceiros de tema merece destaque.

A forma como o autor expõe a metodologia que utilizou transformao início do Tomo I numa meta metodologia, numa lição de como deve ser conduzido um trabalho de pesquisa. Recomendo que se divulgue para os formandos que precisam fazer seus TCCs, para as
\end{abstract}


disciplinas de Teoria e Metodologia da Pesquisa e para os mestrados, esse passo a passo metodológico completo, simples e bem escrito.

São três categorias principais abordadas notrabalho, complexas e inesgotáveis para a área deestudo: Identidade, Direito e Transtorno Mental. E por que alguém escolhe como trabalho acadêmico desvelar a identidade e o direito dos loucos? Por que alguém se incomoda com esta categoria? Por que alguém se debruça sobre os esquecidos, os estigmatizados pelo rótulo de loucura e de criminoso e por isso invisíveis, massacrados e massificados? Manoel Valente Figueiredo Neto responde a essa pergunta com resposta subjetiva, logo no início do livro, e a referenda ao longo de toda a obra.

Tendo-se comoreferência que um passo importante para a cidadania e para a concretização dos Direitos Humanos é ouvir as vozes dos que foram silenciados historicamente, o presente trabalho espera dar visilbilidade a um segmento duplamente estigmatizado: por ser louco e por ter cometido fato definido juridicamente como crime. Espera-se com a presente obra, vocalizar o que as pessoas com transtorno mental idealizam, levando em consideração suas próprias concepções enquanto pessoas que vivenciam o cotidiano das tensões entre o discurso e o poder-saber/Justiça-Psiquiatria (FIGUEIREDO NETO, 2013, p.26).

Ressaltoainda a contextualização histórica que situa o leitor da forma como o tema tem sido tratado dentro da Política Nacional de Saúde e como a sociedade tem enfrentado as questões relativas aos transtornos mentais. Para além de tudo, a linguagem empregada por Manoel Valente Figueiredo Neto, já ressaltada no início desta apresentação, é clara, de fácil entendimento e o tema é humanizado de forma artística pelas epígrafes poéticas que dão o toque literário aos capítulos. Felicito a esta Academia que abre suas portas para o lançamento de uma obra tão necessária a quem trabalha com o Direito e as humanidades. Não posso deixar de citar os dois últimos parágrafos do livro quando o autor faz uma exortação a quantos fazem interface com os loucos:

\begin{abstract}
Discute-se muito sobre educação, lato sensu, como solução/amenização de problemas. Porém, quando se pensa nos direitos e políticas públicas voltadas as pessoas com trantorno mental, nota-se uma lacuna quando o assunto é transmitir mínimos conhecimentos para os loucos, sejam estes científicos, sociais, artísticos, culturais, esportivos. E quando os mesmos são infratores penais, parece que esta lacuna vira um abismo.Não se pode subestimar uma pessoa com transtorno mental, ela é capaz de aprender, apreender e produzir, resguardando as suas peculiaridades. A pessoa com trantorno mental deve ser incentivada a educação, se a ensina conteúdos de sua realidade e determinados parâmetros de justiça e equidade, auxilia-se na promoção dos seus clássicos direitos fundamentais da liberdade e da igualdade (FIGUEIREDO NETO, 2013, p.157).
\end{abstract}

Não posso me furtar ao viésacadêmicoda classificação, esse é o mote da ciência: classificar, selecionar, adjetivar; sejam moléculas, átomos, reações químicas ou a descoberta de um novo planeta ou uma nova galáxia. Além do que premida pelo hábito jornalístico de coletar, apresentar e opinar, tenho gana de encontrar categorias nas quais Manoel Valente Figueiredo Neto se encaixe: louco, santo, poeta, profeta, dentre outras. Louco por escolher os loucos como categoria de estudo e dentro dessa afirmação não preciso dizer mais nada. Santo pela ética que os caracteriza e essa abordagem cumpre em plenitude essa exigência. Poeta pela similitude entre as duas instâncias. E Profeta por acreditar e contribuir para que as políticas públicas cumpram o seu papel de defesa dos ininputáveis e a sociedade gradativamente aprenda a viver com a diferença e os diferentes.

Parabéns Manoel Valente. E, para homenageá-lo, trago uma prosa sobre a loucura de autoria deGibran Khalil Gibran que viveu de 1883 a 1931.

O Louco (Gibran Khalil Gibran)

Perguntais-me como me tornei louco. Aconteceu assim:Um dia, muito tempo antes de muitosdeuses terem nascido, despertei de um sono profundo e notei que todas as minhas máscaras tinham sido roubadas - as sete máscaras que eu havia confeccionado e usado em sete vidas - e corri sem máscara pelas ruas cheias de gente gritando: “Ladrões, ladrões, malditos ladrões!". Homens e mulheres riram de mim e alguns correram para casa, com medo de mim.E quando cheguei à praça do mercado, um garoto trepado no telhado de uma 
casa gritou:"É um louco!”. Olhei para cima, para vê-lo. O sol beijou pela primeira vez minha face nua.Pela primeira vez, o sol beijava minha face nua, e minha alma inflamou-se de amor pelo sol, e não desejei mais minhas máscaras. E, como num transe, gritei: "Benditos, benditos os ladrões que roubaram minhas máscaras!". Assim me tornei louco.E encontrei tanto liberdade como segurança em minha loucura: a liberdade da solidão e a segurança de não ser compreendido, pois aquele que nos compreende escraviza alguma coisa em nós. 